UDC 615.12:658.8:339.18

DOI: $10.15587 / 2519-4852.2020 .222219$

\title{
THEORETICAL AND APPLIED ASPECTS OF ADAPTIVE MANAGEMENT OF MANUFACTURING PHARMACEUTICAL ENTERPRISES OF UKRAINE
}

\author{
R. Sahaidak-Nikitiuk, K. Holybtsova, N. Demchenko, M. Zarichkova
}

\begin{abstract}
The aim of the article is to analyze the existing problems in the organization of adaptive management of industrial pharmaceutical enterprises in Ukraine.

Materials and methods. The methods used in the study include methods of theoretical generalization, analysis and synthesis, strategic analysis.

Results. It was found that today for the national economy of Ukraine the most effective is the adaptive management for all economic entities of all types of economic activity. It is noted that the management of changes and adaptation to them is of great importance in the adaptive management of manufacturing pharmaceutical enterprises. The role of resource provision in the development of industrial pharmaceutical enterprises is noted, since the development of an economic entity depends on the quality and quantity of resources. An algorithm for solving the problem of forming a resource support system for the development of industrial pharmaceutical enterprises is proposed. A scheme for the formation of a strategy for resource provision of industrial pharmaceutical enterprises is proposed. The article considers the forms of financial support for pharmaceutical sector enterprises that have specific features associated with the specifics of the industry and the demand for its products on the market. It is noted that, despite the listed problems, there is a real opportunity for pharmaceutical manufacturing enterprises to improve their financial position and get certain conditions for their development.

Conclusions. In terms of the problems of organizing adaptive management of industrial pharmaceutical enterprises in Ukraine and possible ways to solve them, one of the most influential factors in the organizational and financial recovery of the industry is the formation of competitive advantages of domestic business entities and an increase in the quality level of managerial decision-making on their development
\end{abstract}

Keywords: analysis, adaptive management, pharmaceutical manufacturing enterprise, organization, development, problem

Copyright (C) 2020, R. Sahaidak-Nikitiuk, K. Holybtsova, N. Demchenko, M. Zarichkova.

This is an open access article under the CC BY license (http://creativecommons.org/licenses/by/4.0).

\section{Introduction}

The current state of the national economy and the increasing dynamism of the external environment have led to the fact that the existing traditional approaches to the development of economic entities no longer respond to the changes that are taking place. Ukrainian enterprises were not ready for strategic planning in modern conditions and prompt adjustment of certain strategic directions of development.

The most effective for the national economy of Ukraine is the adaptive management in economic entities of all types of economic activity. In this regard, special attention needs to be paid to the analysis of problems in the organization of adaptive management of manufacturing pharmaceutical companies, because in the context of COVID-19 the development of the pharmaceutical industry is of particular importance.

Problems in the organization of management of industrial pharmaceutical companies have been considered in the works of many scientists. Thus, in scientific works the standards of pharmaceutical management were considered [1,2], the strategy of import substitution in the pharmaceutical industry, its features and prospects for implementation [3], approaches to the formation of the assortment policy of domestic pharmaceutical companies [4], risk management for quality at the pharmaceutical company $[5,6]$, problems of state and regional management of the pharmaceutical industry [7], macroenvironment for the activities of organizations [8], logistics management of the company [9, 10], the state and prospects of pharmacy [11], competitiveness of companies $[12,13]$, of industrial enterprise development strategy $[14,15]$, operation of a business entity in the context of globalization [16], adaptive management of enterprise competitiveness $[17,18]$ and others.

However, despite the significant achievements of these scientists, some aspects of adaptive management of manufacturing pharmaceutical companies in Ukraine have not been studied and require careful study.

The aim of the study. The purpose of the article is to analyze the existing problems in the organization of adaptive management of production pharmaceutical enterprises of Ukraine.

\section{Planning (methodology) of research}

The study was conducted in several stages (Fig. 1). 


\begin{tabular}{|c|c|}
\hline First stage & Studying of the scientific works on the researched issues studied \\
\hline Second stage & $\begin{array}{r}\text { Summarizing the characteristics of the parameters of } \\
\text { management process and adaptive management of the } \\
\text { development of manufacturing pharmaceutical enterprise }\end{array}$ \\
\hline Third stage & $\begin{array}{r}\text { Determining the links between the nature of changes and } \\
\text { reactions of the manufacturing pharmaceutical companies }\end{array}$ \\
\hline Fourth stage & $\begin{array}{r}\text { Algorithm development for solving the problem of forming a } \\
\text { resource provision system for the manufacturing } \\
\text { pharmaceutical enterprises }\end{array}$ \\
\hline Fifth stage & $\begin{array}{r}\text { Studying the forms of financing of manufacturing } \\
\text { pharmaceutical companies }\end{array}$ \\
\hline Sixth stage & $\begin{array}{r}\text { Formulation of specific problems of the pharmaceutical } \\
\text { industry }\end{array}$ \\
\hline
\end{tabular}

Fig. 1. Algorithm of the research

\section{Materials and methods}

The methods used in the study include methods of theoretical generalization, which was used to characterize the parameters of management and adaptive management of the development of a manufacturing pharmaceutical company; analysis and synthesis - in connection with the nature of changes and reactions to them of the manufacturing pharmaceutical company; strategic analysis - in the formation of the strategy of resource provision of manufacturing pharmaceutical companies.

\section{Research results}

The application of an adaptive approach to the management of manufacturing pharmaceutical companies is due to the existence of certain serious threats:

- growing competition with imported medicines;

- rising prices for active pharmaceutical ingredients, basic and auxiliary materials;

- lack of close ties with suppliers of active pharmaceutical ingredients, basic and auxiliary materials;

- concentration of production capacity in large cities;

- ineffective marketing policy;

- lack of reliable forecasts of the speed of oscillations of the environment, etc.

The results of ignoring these threats to manufacturing pharmaceutical companies are a decrease in the level of use of existing production capacity and the overall efficiency of production and economic activities [19].
Characteristics of the parameters of the process of managing the development of the production pharmaceutical company and the option of adaptive management are given in Table 1 .

In the adaptive management of manufacturing pharmaceutical companies of great importance is the management of change and adaptation to them.

The nature of the change depends on the volume of production of medicines, the state of the environment, quality, cost and price of medicines. The task of change management is to choose a vector of change that will give the desired (under the most favorable conditions the maximum) effect with limited resources and costs (Table 2).

Of particular importance for adaptive enterprise management is the ratio of accuracy and speed of management response to changes in the environment and the rate of change of the macroenvironment, i.e. the ratio of accuracy and speed of directed changes in the internal environment compared to the speed and direction of changes in the environment.

Another problem of the organization of adaptive management of manufacturing pharmaceutical companies is the provision of resources, as the quality and quantity of resources depends on the development of the business entity.

That is, quality resource management is about solving a large number of problems in the existing business environment. 
Characteristics of the parameters of the process of management and adaptive management of the development of the manufacturing pharmaceutical enterprise

\begin{tabular}{|c|c|c|}
\hline \multirow[t]{2}{*}{ Parameters } & \multicolumn{2}{|c|}{ Characteristics of parameters } \\
\hline & development management & adaptive development management \\
\hline $\begin{array}{l}\text { The nature of the man- } \\
\text { agement process }\end{array}$ & $\begin{array}{c}\text { - passive, which is due to a sharp decline in sales } \\
\text { and growing competition; } \\
\text { - active, focused on competition and adaptation to } \\
\text { new conditions }\end{array}$ & $\begin{array}{l}\text { - active, focused on competition and } \\
\text { adaptation to new conditions }\end{array}$ \\
\hline Management system & \multicolumn{2}{|c|}{$\begin{array}{c}\text { Centralized } \\
\text { Decentralized }\end{array}$} \\
\hline $\begin{array}{l}\text { The degree of flexibility } \\
\text { of the control system }\end{array}$ & $\begin{array}{l}\text { - determined by: adaptation to current conditions } \\
\text { and maintaining this ability for a long period; } \\
\text { anticipating and preparing for change }\end{array}$ & $\begin{array}{l}\text { - determined by: adaptation to cur- } \\
\text { rent conditions and maintaining this } \\
\text { ability for a long period; strategic } \\
\text { forecasting of forthcoming changes } \\
\text { and preparation for them }\end{array}$ \\
\hline $\begin{array}{l}\text { The nature of strategies } \\
\text { used in the management } \\
\text { decision-making process } \\
\text { for the development of } \\
\text { the enterprise }\end{array}$ & $\begin{array}{c}\text { - evolutionary - strategies aimed at using internal } \\
\text { potential and external opportunities to adapt to } \\
\text { change; } \\
\text { - revolutionary - strategies aimed at actively } \\
\text { using the internal potential to change the external } \\
\text { environment }\end{array}$ & $\begin{array}{l}\text { - Evolutionary - strategies aimed at } \\
\text { using internal capacity and external } \\
\text { opportunities to adapt to change }\end{array}$ \\
\hline
\end{tabular}

Table 2

The relationship between the nature of changes and reactions to them of the manufacturing pharmaceutical company

\begin{tabular}{|c|c|c|}
\hline The nature of the changes & Characteristic & Reaction \\
\hline Changes in market demand & Passive or active & Changing the type of product \\
\hline Changes in tax policy & By input variable & Changing the size of the enterprise \\
\hline Changes in competitors' behavior & Strategic & $\begin{array}{c}\text { Changes in pricing policy, strategy, production vol- } \\
\text { umes, markets }\end{array}$ \\
\hline Changes in consumer requirements & Extreme & $\begin{array}{c}\text { Change of quality, management, marketing, logistics, } \\
\text { production }\end{array}$ \\
\hline Changes in the quality of staff work & Control & Retraining, advanced training, selection, recruitment \\
\hline
\end{tabular}

«An internally efficient organization rationally uses all types of resources: labor, material, financial, energy, while producing goods and services with minimal costs and high quality». In this case, increasing internal efficiency is primarily the task of "classical" management and overall efficiency is determined by multiplying its individual components:

$$
E=E_{1} \times E_{2}
$$

where $E$ - overall efficiency; $E_{1}-$ level of external efficiency (degree of use of market opportunities); $E_{2}-$ level of internal efficiency (degree of use of internal opportunities).

Resource provision of the enterprise is a set of measures to provide the enterprise with resources of the appropriate type and composition, which includes mechanisms for finding, obtaining, storing, accumulating, planning, accounting, use and costs. The structure of resource provision for each organization is individual, based on the specifics of the industry in which it operates, the level of economic development, the state of development potential, the chosen strategy for further development, etc.
The development of strategic goals of the enterprise should be based, in particular, on the analysis of the composition of resources, the state of their use by individual types, identifying potential opportunities to attract additional resources if necessary.

First of all, the resource provision of enterprise development should be based on the law of development of the organization: each material system seeks to achieve the greatest total potential during all stages of the life cycle. Analytically, this can be recorded as follows [20]:

$$
\begin{aligned}
& R_{j}=\sum_{i=1}^{n}\left(R_{i j}\right), \\
& K_{j}=F_{j}\left(K_{j+1}, \ldots, K_{m}\right), \\
& \sum_{i=1}^{m}\left(K_{j} \times R_{j}\right) \rightarrow R_{\max },
\end{aligned}
$$

where $R_{j}$ - potential (resource) of the system in any field at the stage $\mathrm{j} ; K_{j}-$ the weighting factor of the influence of each previous potential (stage) on the following; $F_{j}$-influence function; $R_{\max }$ - planned results for specific activities; $i=\overline{1: n}$ - areas of activity of the organization; $j=\overline{1: m}$ - stage of the life cycle of the organization. 
The solution of the problem of forming a system of resource provision for the development of industrial pharmaceutical enterprises can be presented in the form of an algorithm:

- identification of existing problems regarding the resource provision of enterprises;

- identification of the most important factors and development of means to solve the tasks;

- analysis of the existing resource management system of manufacturing pharmaceutical companies and identification of individual shortcomings;

- assessment of the degree of impact of certain shortcomings on the resource management system of economic entities;

- selection of alternative options for improving the resource management system, which would allow to achieve the relevant efficiency criteria;

- improvement of the resource management sys- tem of economic entities;

- evaluation of the obtained results.

In our opinion, the rational use of production resources and management of these processes should be organized along with other important components of adaptive management for the enterprises of the industry, which will significantly affect the current state and prospects of development of manufacturing pharmaceutical enterprises. The scheme of formation of the resource provision strategy of manufacturing pharmaceutical enterprises is shown in Fig. 2.

It can be argued that the strategy of resource provision is also a set of principles, factors, methods, measures to ensure a steady reduction in total resources per unit of gross national product (within the country) or per unit of benefit of a particular product while ensuring the security of the country, ecosystem, regions, companies, people.

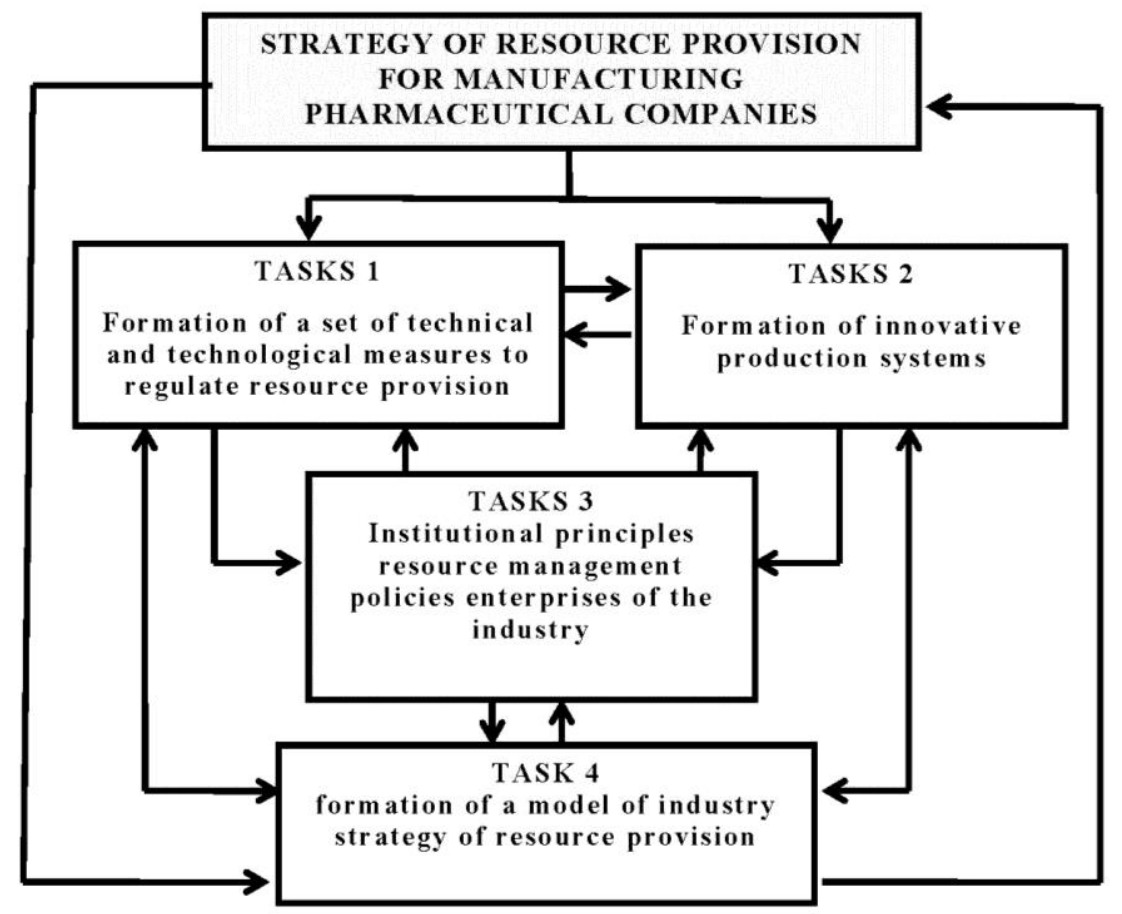

Fig. 2. Formation of strategy of resource provision of production pharmaceutical enterprises

Thus, the purpose of resource provision of manufacturing pharmaceutical enterprises is to create conditions conducive to the normal functioning of economic activity, the implementation of planned plans, programs, maintaining stable and uninterrupted operation of enterprises in the pharmaceutical sector.

Today, given the instability of the economic environment and the banking sector in Ukraine in the last few years, the issue of financial support for the development of manufacturing pharmaceutical companies is one of the most important. Pharmaceuticals is one of the few areas that suffered less from the crisis in 2020 and is recovering more actively than others. Manufacturing pharmaceutical companies continue to invest heavily in the development of new drugs, digitalization and innovation, as well as in building relationships with consumers.
However, the financial support of the pharmaceutical sector has a number of specific features, which are related to the specifics of the industry and the demand for its products on the market. Forms of financing of manufacturing pharmaceutical companies are presented in Table 3 .

In recent years, the interest of venture companies in the Ukrainian market and manufacturing pharmaceutical companies has grown significantly. This is evidenced by the opening of representative offices of certain companies in our country.

Using a venture form of financing for manufacturing pharmaceutical companies is the fastest opportunity for businesses to use all available resources to create new products, accelerate innovation, increase the scientific and technical level of production and create a competitive environment in domestic and foreign markets. 
Possible forms of financing of manufacturing pharmaceutical enterprises

\begin{tabular}{|c|c|c|}
\hline \multirow{2}{*}{$\begin{array}{l}\text { Forms of } \\
\text { financing }\end{array}$} & \multicolumn{2}{|c|}{ Financial resources for the development of organizational and resource potential } \\
\hline & general security & special support \\
\hline Self-financing & $\begin{array}{l}\text { - funds advanced to fixed and current assets of } \\
\text { enterprises; } \\
\text { - profit; } \\
\text { - depreciation; } \\
\text { - funds received from another type of activity }\end{array}$ & $\begin{array}{l}\text { - reserve fund; } \\
\text { - currency fund }\end{array}$ \\
\hline Lending & $\begin{array}{l}\text { - commercial loans; } \\
\text { - bank loans }\end{array}$ & $\begin{array}{l}\text { - overdraft in foreign currency; } \\
\text { - loans in foreign currency; } \\
\text { - loans of intermediaries; } \\
\text { - financing through commission firms; } \\
\text { - lending by foreign banks }\end{array}$ \\
\hline Raising funds & $\begin{array}{l}\text { - sale of own shares and other types of securi- } \\
\text { ties; } \\
\text { - dividends and interest on securities; } \\
\text { - investments }\end{array}$ & $\begin{array}{l}\text { - Eurobonds; } \\
\text { - location of shares on foreign markets; } \\
\text { - foreign investments; } \\
\text { - promissory notes and checks }\end{array}$ \\
\hline $\begin{array}{l}\text { Budget financ- } \\
\text { ing }\end{array}$ & $\begin{array}{l}\text { - budget subsidies; } \\
\text { - grants }\end{array}$ & $\begin{array}{l}\text { - credit of joint state institutions; } \\
\text { - state grants }\end{array}$ \\
\hline $\begin{array}{l}\text { Venture } \\
\text { financing }\end{array}$ & $\begin{array}{l}\text { - pension funds; } \\
\text { - insurance companies; } \\
\text { - large corporations; } \\
\text { - banks }\end{array}$ & $\begin{array}{l}\text { - private investors; } \\
\text { - "business angels" }\end{array}$ \\
\hline $\begin{array}{l}\text { Additional war- } \\
\text { ranty }\end{array}$ & $\begin{array}{l}\text { - bank guarantees; } \\
\text { - insurance }\end{array}$ & $\begin{array}{l}\text { - advances of the buyer; } \\
\text { - structured financing }\end{array}$ \\
\hline
\end{tabular}

Another means of obtaining financial resources for manufacturing pharmaceutical companies is the issue of bonds, which has unconditional advantages. The issuance of bonds makes it possible to obtain financial income for a sufficiently long period without collateral at fairly democratic interest rates. In addition, the owner of the enterprise has the ability to manage the enterprise and control all production and financial processes.

\section{Discussion of research results}

Therefore, on the basis of the conducted researches it is defined that strategic investors are mainly pharmaceutical companies interested in business expansion.

It should be noted that the pharmaceutical market in Ukraine is financed mainly by the population. The share of public procurement does not significantly affect its development. At the same time, opioids, cephalosporin antibiotics and infusion solutions are in the lead in public procurement. The latter account for almost a third of hospital purchases. For example, $99 \%$ of expenditures on medicines in Ukraine are financed directly by the population, while in European countries a significant share of expenditures is covered by health insurance and state social protection programs. Drug consumption per person in Ukraine is 73 USD, which is about 10 times less than in the US [21].

As for the positive dynamics of growth in the volume of pharmaceutical products in Ukraine, this is primarily due to the pandemic and the ability of the population to buy drugs.

As a result of the study of existing problems in the organization of adaptive management of manufacturing pharmaceutical enterprises of Ukraine, it was found that effective management of all types of resources of economic entities is an important component of their development and improving the financial and economic situation.
But there is a real opportunity for manufacturing pharmaceutical companies to improve their financial situation and get the conditions for development. Thus, on the basis of the conducted researches, we have formed the basic directions of an exit of the Ukrainian pharmaceutical enterprises on the world and national markets:

- the projected growth of the world pharmaceutical market provides opportunities for export development for Ukrainian manufacturing pharmaceutical companies and expands their markets;

- the growth of the domestic pharmaceutical market provides opportunities to expand the product portfolio and increase sales of pharmaceutical products;

- the existing scientific potential for research and innovative developments is the basis for the development of the segment of original medicines under the condition of investment;

- the predominance of generic drugs in the domestic pharmaceutical market provides opportunities for diversification of activities and expansion of markets;

- introduction of international standards for quality assurance and control of pharmaceutical products promotes integration into international processes and increases the competitiveness of domestic manufacturers [22].

That is, there is a real opportunity for manufacturing pharmaceutical companies to take a worthy place in the domestic pharmaceutical market and address the issue of entering international markets, using the available development potential.

Study limitations. The research is possible only in a market economy.

The prospect for further research should be to determine the current state and improve the quality of management decisions for the development of manufacturing pharmaceutical companies. 


\section{Conclusions}

In the perspective of certain problems in the organization of adaptive management of production pharmaceutical enterprises of Ukraine and possible ways to solve them, it can be noted that one of the most influential factors of organizational and financial recovery is the formation of competitive advantages of domestic entities and improving management decisions on pharmaceutical development. in Ukraine.
The prospect for further research should be to determine the current state and improve the quality of management decisions for the development of manufacturing pharmaceutical companies.

\section{Conflicts of interest}

The authors declare that there is no conflict of interests.

\section{References}

1. Sieckmann, F., Ngoc, H. N., Helm, R., Kohl, H. (2018). Implementation of lean production systems in small and mediumsized pharmaceutical enterprises. Procedia Manufacturing, 21, 814-821. doi: http://doi.org/10.1016/j.promfg. 2018.02.188

2. Anusha, K., Krishna, P. P., Praveen, K. V. (2014). Pharmaceutical product management. The Pharma Innovation Journal, 6 (11), 112-114.

3. Demchenko, N. V. (2014). Stratehiia importozamishchennia u farmatsevtychnii haluzi: osoblyvosti i perspektyvy realizatsii. Visnyk Odeskoho natsionalnoho universytetu. Seriia: Ekonomika, 19 (2), 56-60.

4. Kotvitska, A. A., Kostiuk, V. H. (2016). Doslidzhennia suchasnykh pidkhodiv do formuvannia asortymentnoi polityky vitchyznianykh farmatsevtychnykh pidpryiemstv. Sotsialna farmatsiia v okhoroni zdorovia, 2, 37-43.

5. ISO 31000:2018 Risk management - Guidelines (2018). International Standard, 16.

6. IEC 31010:2019 Risk management - Risk assessment techniques (2019). International Standard, 264.

7. Nemchenko, A. S., Nazarkina, V. M., Panfilova, H. L. (2015). Orhanizatsiia ta ekonomika farmatsii. Ch. 1. Orhanizatsiia farmatsevtychnoho zabezpechennia naselennia. Kharkiv: Zoloti storinky, 360

8. Prasanth, S. P., Jagathy, R. V. P., Pramod, V. R. (2015). Total Productive Maintenance and Role of Interpretive Structural Modeling and Structural Equation Modeling in Analyzing Barriers in Its Implementation - A Literature Review. International Journal of Scientific \& Technology Research, 4 (9), 302-315.

9. Raue, J. S., Wieland, A. (2015). The interplay of different types of governance in horizontal cooperations. The International Journal of Logistics Management, 26 (2), 401-423. doi: http://doi.org/10.1108/ijlm-08-2012-0083

10. Adobor, H. (2020). Supply chain resilience: an adaptive cycle approach. The International Journal of Logistics Management, 31 (3), 443-463. doi: http://doi.org/10.1108/ijlm-01-2020-0019

11. Bellm, D. (2015). Operational Excellence in the Pharmaceutical Industry - An Architecture for Emerging Markets. St. Gallen.

12. Sundareshan, S. D. (2015). A Literature Review on Lean Implementations - A comprehensive summary. International Journal of Engineering Research and Applications, 1 (5), 73-81

13. Nedelko, Z., Potocan, V., \& Dabić, M. (2015). Current and future use of management tools. E+M Ekonomie a Management, 18, 28-45. doi: http://doi.org/10.15240/tul/001/2015-1-003

14. Kwilinski, A. (2018). Mechanism of formation of industrial enterprise development strategy in the information economy. Virtual Economics, 1 (1), 7-25. doi: http://doi.org/10.34021/ve.2018.01.01(1)

15. Kwilinski, A. (2018). Mechanism of modernization of industrial sphere of industrial enterprise in accordance with requirements of the information economy. Marketing and Management of Innovations, 4, 116-128. doi: http://doi.org/10.21272/mmi.2018.4-11

16. Payonk, K., Lyashenko, V., Kvilinskyi, O. (2015). Operation of a business entity in the context of globalization. Economic Herald of the Donbas, 4 (42), 18-23.

17. Starikova, M. S., Mishin, D. A., Nikitina, E. A. (2016). Assessment of Quality of Adaptive Management of Industrial Corporation in the Competitive Environment. International Journal of Pharmacy \& Technology, 8 (4), 22473-22485.

18. Farhshatova, O., Zaharov, S., Vereskun, M., Kolosok, V. (2019). Formation of Competitive Advantages of the Enterprise Based on Adaptive Management. Marketing and Management of Innovations, 1, 244-256. doi: http://doi.org/10.21272/mmi.2019.1-21

19. Siketina, N. H.; Bezpartochnyi, M., Britchenko, I. (Eds.) (2019). Adaptive development of competitive advantages of an industrial enterprise on the basis of analysis and ensuring the competitiveness of its products. Conceptual aspects management of competitiveness the economic entities. Vol. 2. Przeworsk: WSSG, 98-107.

20. Martynenko, V. P. (2006). Stratehiia zhyttiezdatnosti pidpryiemstv promyslovosti. Kyiv: Tsentr navchalnoi literatury, 328

21. Ostashko, T. O. (Ed.) Strukturni zminy u svitovii torhivli yak chynnyk rozvytku vnutrishnoho rynku Ukrainy. Kyiv, 350.

22. Kubareva, V. (2020). Otsinka farmatsevtychnoi haluzi Ukrainy u konteksti investytsiinoi pryvablyvosti yii kompanii. Available at: https://core.ac.uk/download/pdf/32612758.pdf

Received date 17.11.2020

Accepted date 21.12.2020

Published date 30.12.2020

Rita Sahaidak-Nikitiuk, Doctor of Pharmaceutical Sciences, Professor, Department of of Management and Economics of Enterprise, National University of Pharmacy, Pushkinska str., 53, Kharkiv, Ukraine, 61002,

E-mail: management@nuph.edu.ua

Karyna Holybtsova, Head of Department, Postgraduate Department, National University of Pharmacy, Pushkinska str., 53, Kharkiv, Ukraine, 61002, E-mail: aspirantura@nuph.edu.ua

Nataliya Demchenko, PhD, Associate Professor, Department of Management and Administration, National University of Pharmacy, Pushkinska str., 53, Kharkiv, Ukraine, 61002, E-mail: demchenata@ukr.net

Mariya Zarichkova, Doctor of Pharmaceutical Sciences, Associate Professor, Department of Management and Economics of Pharmacy, Institute for Advanced Training of Pharmacy Specialists of National University of Pharmacy, Zakhysnykiv Ukrainy sq., 17, Kharkiv, Ukraine, 61001, E-mail: zarichkova@ukr.net 